\title{
PENGARUH KEPUTUSAN INVESTASI, KEPUTUSAN PENDANAAN DAN KEBIJAKAN DIVIDEN TERHADAP NILAI PERUSAHAAN FOOD AND BEVERAGES
}

\author{
Asri Pawestri Setyo Utami ${ }^{1}$ \\ Ni Putu Ayu Darmayanti² \\ ${ }^{1,2}$ Fakultas Ekonomi dan Bisnis Universitas Udayana (Unud), Bali, Indonesia \\ e-mail: asripsu@gmail.com
}

\begin{abstract}
ABSTRAK
Perusahaan yang ingin memaksimalkan nilai perusahaan, akan mengambil beberapa keputusan diantaranya keputusan investasi, kebijakan dividen, serta keputusan pendanaan. Tujuan penelitian ini adalah untuk menjelaskan pengaruh keputusan investasi, keputusan pendanaan, dan kebijakan dividen terhadap nilai perusahaan food and beverages yang terdaftar di Bursa Efek Indonesia. Sampel yang digunakan dalam penelitian ini dipilih secara sampling jenuh. Data sekunder yang diperoleh kemudian dipilih berdasarkan kriteria-kriteria yang telah ditentukan, maka diperoleh sebanyak 13 sampel selama periode tahun 2013-2016. Teknik analisis data yang digunakan adalah analisis regresi linear berganda. Hasil penelitian menunjukkan bahwa keputusan investasi, keputusan pendanaan, dan kebijakan dividen berpengaruh positif dan signifikan terhadap nilai perusahaan food and beverages. Saran yang dapat diberikan adalah agar lebih memperhatikan lagi faktor internal perusahaan. Variabel tersebut dapat dijadikan acuan untuk menentukkan strategi dalam meningkatkan nilai perusahaan. Nilai perusahaan yang baik menunjukan tingkat kesehatan keuangan perusahaan yang baik sehingga membuat nilai perusahaan akan meningkat dan diminati oleh investor.

Kata Kunci: keputusan investasi, keputusan pendanaan, kebijakan dividen, nilai perusahaan
\end{abstract}

\begin{abstract}
Companies that want to maximize the value of the company, will take some decisions such as investment decisions, dividend policies, and funding decisions. The purpose of this study is to explain the effect of investment decisions, funding decisions, and dividend policy on the value of food and beverages companies listed on the Indonesia Stock Exchange. The samples used in this study were selected in saturation sampling. Secondary data obtained then selected based on predetermined criteria, then obtained as many as 13 sample during period of year 2013-2016. Data analysis technique used is multiple linear regression analysis. The results showed that investment decisions, funding decisions, and dividend policies have a positive and significant impact on the value of food and beverages companies. The suggestion that can be given is to pay more attention to internal factors of the company. These variables can be used as a reference to establish a strategy in increasing the value of the company. Good corporate value shows the level of good corporate financial health so as to make the value of the company will be increased and in demand by investors.

Keywords: investment decision, fund decision, dividend policy, corporate value
\end{abstract}


Asri Pawestri Setyo Utami, Pengaruh Keputusan Investasi, Keputusan Pendanaan dan ...

\section{PENDAHULUAN}

Perusahaan - perusahaan industri manufaktur khususnya di sektor food and beverages di Indonesia semakin hari semakin berkembang, hal ini dapat dilihat dari semakin bertambahnya jumlah perusahaan food and beverages di Bursa Efek Indonesia. Pertumbuhan industri ini terutama didorong kecenderungan masyarakat khususnya kelas menengah ke atas yang mengutamakan konsumsi produk-produk makanan dan minuman yang higienis dan alami. Industri makanan dan minuman juga mempunyai peranan penting dalam pembangunan sektor industri.

Kecenderungan masyarakat Indonesia untuk menikmati makanan Ready to eat menyebabkan volume kebutuhan terhadap food and beverage terus meningkat, sehingga banyak bermunculan perusahaan baru dibidang makanan dan minuman. Oleh karena itu persaingan antar perusahaan pun semakin kuat. Perusahaan sebagai entitas ekonomi umumnya memiliki tujuan jangka pendek dan jangka panjang. Tujuan jangka pendek perusahaan yaitu memperoleh laba secara maksimal dengan menggunakan sumber daya yang ada, sementara tujuan jangka panjang perusahaan adalah memaksimalkan nilai perusahaan (Saputri dkk., 2016). Jadi semakin tinggi nilai perusahaan maka semakin besar kemakmuran yang akan diterima oleh pemilik perusahaan (Fernandar dan Raharja, 2012).

Perusahaan yang ingin mencapai tujuan jangka panjang yaitu memaksimalkan nilai perusahaan, maka akan mengambil beberapa keputusan berupa keputusan investasi, keputusan pendanaan dan kebijakan dividen. Ketiga keputusan keuangan tersebut merupakan keputusan yang saling berkaitan satu sama lainnya serta mempengaruhi nilai perusahaan (Sartini dan Purbawangsa, 2014). 
Nilai perusahaan adalah istilah yang digunakan untuk menunjukkan kesehatan keuangan dan keadaan perusahaan jangka panjang.

Nilai perusahaan diukur dengan Price Book Value (PBV), Rasio ini merupakan rasio antara harga saham terhadap nilai bukunya. Perusahaan yang berjalan dengan baik umumnya mempunyai rasio PBV di atas satu, yang menunjukkan bahwa nilai pasar saham lebih besar dari nilai bukunya (Wardjono, 2010). Nilai perusahaan yang tidak go public merupakan harga yang bersedia dibayarkan oleh investor apabila perusahaan tersebut dijual. Sementara untuk perusahaan go public nilai perusahaan akan tercermin dari harga sahamnya.

Nilai perusahaan yang semakin tinggi akan membuat semakin tinggi pula kemakmuran yang akan diterima oleh pemegang saham. Meningkatkan kemakmuran para pemegang saham, perusahaan dapat melaksanakan keputusankeputusan dibidang keuangan (keputusan investasi, keputusan pendanaan, dan kebijakan dividen), sedemikian rupa sehingga harga saham meningkat dan dengan meningkatnya harga saham sudah tentu akan diikuti oleh meningkatnya nilai perusahaan (Dananjaya dan Mustanda, 2016).

Keputusan investasi merupakan faktor yang sangat penting dalam fungsi keuangan perusahaan, dimana jika semakin tinggi keputusan investasi yang ditetapkan oleh perusahaan maka semakin tinggi kesempatan perusahaan dalam memperoleh return atau tingkat pengembalian yang besar. Karena dengan perusahaan yang memiliki keputusan investasi yang tinggi maka mampu untuk mempengaruhi pemahaman investor terhadap perusahaan, sehingga mampu meningkatkan permintaan terhadap saham perusahaan tersebut (Pertiwi dkk., 
Asri Pawestri Setyo Utami, Pengaruh Keputusan Investasi, Keputusan Pendanaan dan ...

2016). Keputusan investasi dalam penelitian ini diukur dengan proksi rasio aktiva tetap (Fixed Asssets Ratio), karena penelitian ini lebih memfokuskan untuk melihat proporsi aktiva tetap perusahaan. Selain itu, rasio aktiva tetap sangat membantu dalam mengevaluasi kemampuan suatu perusahaan menggunakan basis asetnya secara efektif dalam menghasilkan pendapatan, sehingga diasumsikan lebih efektif untuk pengambilan keputusan investasi. Rasio ini menunjukkan seberapa besar proporsi aktiva tetap terhadap seluruh aktiva perusahaan. Rasio yang tinggi menunjukkan penggunaan (proporsi) aktiva tetap perusahaan juga tinggi. FAR dihitung dengan membandingkan total aktiva tetap terhadap total seluruh aktiva perusahaan.

Tujuan dilakukannya keputusan investasi adalah mendapat laba yang besar degan risiko yang dapat dikelola dengan harapan dapat mengoptimalkan nilai perusahaan. Keputusan investasi berpengaruh terhadap nilai perusahaan menunjukkan bahwa adanya sejumlah investasi yang akan mendapat surplus jika perusahaan mampu membuat keputusan investasi yang tepat. Surplus yang diperoleh akan memberikan kontribusi terhadap cash inflow, kemudian diakumulasikan pada peningkatan profit perusahaan (Safitri dan Wahyuati, 2015).

Keputusan investasi yang tepat diharapkan dapat memberikan pertumbuhan positif baik untuk perusahaan maupun investor. Bagi investor pertumbuhan positif merupakan suatu prospek yang menguntungkan, karena investasi yang ditanamkan dapat memberikan return optimal di masa yang akan datang. Dananjaya dan Mustanda (2016) dalam penelitiannya memperoleh hasil bahwa keputusan investasi berpengaruh positif signifikan terhadap nilai perusahaan. Semakin baik keputusan 
investasi dalam suatu perusahaan maka nilai perusahaan yang dihasilkan perusahaan akan semakin tinggi.

Keputusan pendanaan dapat diartikan sebagai keputusan yang menyangkut struktur keuangan perusahaan. Struktur keuangan perusahaan merupakan komposisi dari keputusan pendanaan yang meliputi hutang jangka pendek, hutang jangka panjang dan modal sendiri. Setiap perusahaan akan mengharapkan adanya struktur modal optimal, yaitu struktur modal yang dapat memaksimalkan nilai perusahaan (Fernandar dan Raharja, 2012). Keputusan pendanaan perusahaan dihitung dengan menggunakan rasio DAR (Debt to Asset Ratio). Rasio ini menyatakan proporsi hutang perusahaan terhadap ekuitasnya sehingga dapat menunjukkan bagaimana manajemen mengelola sumber dananya (Himawan dan Christiawan, 2016). Afzal dan Rohman (2012) memperoleh hasil bahwa keputusan pendanaan berpengaruh positif dan signifikan terhadap nilai perusahaan.

Satu lagi kebijakan yang harus diperhatikan dalam mengoptimalkan nilai perusahaan adalah kebijakan dividen dimana para investor memiliki tujuan utama untuk meningkatkan kesejahteraan dengan mengharapkan pengembalian dalam bentuk dividen maupun capital gain, sedangkan perusahaan mengharapkan pertumbuhan secara terus menerus untuk mempertahankan kelangsungan hidupnya sekaligus memberikan kesejahteraan kepada para pemegang sahamnya (Afzal dan Rohman, 2012). Kebijakan dividen akan berdampak terhadap besarnya laba ditahan perusahaan yang merupakan sumber pendanaan internal perusahaan yang akan digunakan untuk mengembangkan perusahaan di masa yang akan datang (Uwigbe et al., 2012). 
Asri Pawestri Setyo Utami, Pengaruh Keputusan Investasi, Keputusan Pendanaan dan ...

Kebijakan dividen diproksikan dalam bentuk Dividend Payout Ratio (DPR). Rasio pembayaran dividen adalah persentase laba dibayarkan kepada para pemegang saham dalam bentuk kas. Dalam keputusan pembagian dividen perlu mempertimbangkan kelangsungan hidup dan pertumbuhan perusahaan. Bagi investor yang berinvestasi tentunya tingkat return atau keuntungan yang akan diperoleh dari investasi yang ditanamkannya berupa capital gain dan deviden yang merupakan bagian keuntungan yang diberikan kepada para pemegang saham. Fenandar dan Raharja (2012) dalam penelitiannya memperoleh hasil bahwa kebijakan dividen berpengaruh positif dan signifikan terhadap nilai perusahaan. Berlandaskan pada fenomena bisnis dan hasil-hasil penelitian sebelumnya maka dibutuhkan penelitian lebih lanjut mengenai pengaruh keputusan investasi, keputusan pendanaan dan kebijakan dividen terhadap nilai perusahaan Food and Beverages yang terdaftar di Bursa Efek Indonesia.

Berdasarkan latar belakang yang telah diuraikan diatas, sehingga pokok permasalahan dalam penelitian ini adalah: 1) Bagaimana pengaruh keputusan investasi terhadap nilai perusahaan food and beverages yang terdaftar di Bursa Efek Indonesia?, 2) Bagaimana pengaruh keputusan pendanaan terhadap nilai perusahaan food and beverages yang terdaftar di Bursa Efek Indonesia?, 3) Bagaimana pengaruh kebijakan dividen terhadap nilai perusahaan food and beverages yang terdaftar di Bursa Efek Indonesia?. Berdasarkan rumusan masalah yang telah diuraikan, maka tujuan penelitian ini adalah sebagai berikut: 1) untuk menjelaskan pengaruh keputusan investasi terhadap nilai perusahaan food and beverages yang terdaftar di Bursa Efek Indonesia, 2) Untuk menjelaskan pengaruh 
keputusan pendanaan terhadap nilai perusahaan food and beverages yang terdaftar di Bursa Efek Indonesia, 3) Untuk menjelaskan pengaruh kebijakan dividen terhadap nilai perusahaan food and beverages yang terdaftar di Bursa Efek Indonesia.

\section{Nilai Perusahaan}

Nilai perusahaan merupakan harga yang bersedia dibayar oleh calon pembeli apabila perusahaan tersebut dijual. Memaksimalkan nilai perusahaan sangat penting artinya bagi suatu perusahaan, karena dengan memaksimalkan nilai perusahaan berarti juga memaksimalkan kemakmuran pemegang saham yang merupakan tujuan utama perusahaan (Husnan, 2004:112). Nilai perusahaan akan tercermin dari harga sahamnya. Harga pasar dari saham perusahaan yang terbentuk antara pembeli dan penjual disaat terjadi transaksi disebut nilai pasar perusahaan, karena harga pasar saham dianggap cerminan dari nilai asset perusahaan sesungguhnya. Nilai perusahaan yang dibentuk melalui indikator nilai pasar saham sangat dipengaruhi oleh peluang-peluang investasi. Adanya peluang investasi dapat memberikan sinyal positif tentang pertumbuhan perusahaan dimasa yang akan datang, sehingga akan meningkatkan harga saham, dengan meningkatnya harga saham maka nilai perusahaan pun akan meningkat. (Eko, 2013).

Maiyarni (2014) menyatakan bahwa nilai perusahaan di pengaruhi oleh dua faktor yaitu faktor internal dan eksternal perusahaan. Faktor internal merupukan sekumpulan variabel yang dapat dikendalikan perusahaan, sedangkan faktor eksternal yang tidak dapat di kendalikan perusahaan. Faktor internal terdiri dari 
Asri Pawestri Setyo Utami, Pengaruh Keputusan Investasi, Keputusan Pendanaan dan ...

profitabilitas, pembayaran dividen, ukuran perusahaan dan pangsa pasar relatif. Faktor eksternal, meliputi tingkat suku bunga, keadaan pasar modal dan pertumbuhan pasar.

\section{Keputusan Investasi}

Keputusan investasi merupakan faktor penting, karena untuk mencapai tujuan perusahaan yaitu memaksimumkan kemakmuran pemegang saham hanya akan dihasilkan melalui kegiatan investasi perusahaan. Tujuan keputusan investasi adalah memperoleh tingkat keuntungan yang tinggi dengan tingkat risiko tertentu. Keuntungan yang tinggi disertai dengan risiko yang bisa dikelola, diharapkan akan menaikkan nilai perusahaan, yang berarti menaikkan kemakmuran pemegangsaham. Dengan kata lain, bila dalam berinvestasi perusahaan mampu menghasilkan keuntungan dengan menggunakan sumber daya perusahaan secara efisien, maka perusahaan akan memperoleh kepercayaan dari calon investor untuk membeli sahamnya. Dengan demikian, semakin tinggi keuntungan perusahaan semakin tinggi nilai perusahaan (Yuliani, 2013). Yuliani (2013) menyebutkan bahwa fokus analisis dalam keputusan investasi terdiri dari tiga aspek yaitu: Pertama, aspek likuiditas yaitu aspek yang berkaitan dengan kemampuan perusahaan dalam melunasi semua kewajiban yang segera jatuh tempo atau termasuk dalam kategori kewajiban jangka pendek. Kedua, Aspek kesempatan investasi yaitu menyangkut bagaimana perusahaan mengkombinasikan asset in place dan memutuskan berbagai pilihan investasi di masa yang akan datang. Ketiga, Aspek financial constraint (hambatan pendanaan) berkaitan dengan keterbatasan 
perusahaan dalam mendapatkan modal dari sumber-sumber pendanaan yang tersedia untuk berinvestasi.

Keputusan investasi akan tercermin pada sisi aktiva perusahaan, dimana dari sisi aktiva dapat diketahui struktur kekayaan perusahaan, yaitu perbandingan antara aktiva lancar dengan aktiva tetap. Sebaliknya keputusan pendanaan dan kebijakan dividen akan tercermin pada sisi pasiva perusahaan. Untuk bisa mengambil keputusan-keputusan keuangan yang benar, manajer keuangan perlu menentukan tujuan yang harus dicapai (Husnan, 2010:7).

\section{Keputusan Pendanaan}

Keputusan Pendanaan berkaitan dengan keputusan perusahaan dalam mencari dana untuk membiayai investasi dan menentukan komposisi sumber pendanaan. Keputusan pembiayaan merupakan salah satu keputusan yang paling kritis dan pekerjaan yang menantang untuk manajer keuangan, hal itu disebabkan karena keputusan ini memiliki dampak langsung pada kinerja keuangan dan struktur modal dari perusahaan (Kumar et al., 2012). Keputusan ini sering disebut sebagai kebijakan struktur modal.

Pada keputusan ini manajer keuangan dituntut untuk mempertimbangkan dan menganalisis kombinasi dari sumber-sumber dana yang ekonomis bagi perusahaan guna mempelajari kebutuhan-kebutauhan investasi. Menurut Brigham dan Houston (2001) dalam Wijaya dan Wibawa (2010), menyatakan bahwa peningkatan hutang diartikan oleh pihak luar tentang kemampuan perusahaan untuk membayar kewajiban di masa yang akan datang atau adanya risiko bisnis yang rendah, hal tersebut akan direspon secara positif oleh pasar. Keputusan pendanaan berkaitan 
Asri Pawestri Setyo Utami, Pengaruh Keputusan Investasi, Keputusan Pendanaan dan ...

dengan keputusan perusahaan dalam mencari dana untuk membiayai investasi dan menentukan komposisi sumber pendanaan (Kumar et al., 2012)

\section{Kebijakan Dividen}

Kebijakan dividen (dividend policy) merupakan keputusan apakah laba yang diperoleh perusahaan pada akhir tahun akan dibagi kepada pemegang saham dalam bentuk dividen atau akan ditahan untuk menambah modal guna pembiayaan investasi di masa yang akan datang. Kebijakan dividen merupakan bagian yang tidak dapat dipisahkan dengan keputusan pendanaan perusahaan (Rudangga, 2016). Kebijakan dividen akan berdampak terhadap besarnya laba ditahan perusahaan yang merupakan sumber pendanaan internal perusahaan yang akan digunakan untuk mengembangkan perusahaan di masa mendatang (Uwigbe et al., 2012).

Salah satu kebijakan yang harus diambil oleh manajemen yaitu memutuskan apakah laba bersih yang diperoleh selama satu periode dibagi semua atau dibagi sebagian untuk dividen dan sebagian lagi tidak dibagi (menjadi laba ditahan) (Brigham dan Houston, 2001). Pembagian dividen haruslah tepat karena dividen yang terlalu tinggi akan mengganggu ekspansi perusahaan, sedangkan dividen yang terlalu rendah akan menurunkan minat investor. Kebijakan dividen yang tepat akan meningkatkan harga saham yang menjadi salah satu indikator nilai perusahaan (Wijaya et al., 2010).

\section{Hipotesis Penelitian}

Keputusan investasi memiliki pengaruh yang signifikan terhadap nilai perusahaan. Semakin tinggi tingkat keputusan investasi yang ditetapkan perusahaan maka akan menghasilkan kesempatan yang tinggi pula untuk mendapatkan 
keuntungan yang besar. Safitri dan Wahyuati (2015) menemukan hasil bahwa keputusan investasi berpengaruh positif dan signifikan terhadap nilai perusahaan semen yang terdaftar di BEI tahun 2009-2013. Hasil ini menunjukkan bahwa keputusan investasi yang semakin meningkat maka nilai perusahaan juga akan meningkat.

Penelitian serupa oleh Yuliani (2013), Fenandar dan Raharja (2012), Afzal dan Rohman, 2012), Dananjaya dan Mustanda (2016), Rizqia et al. (2013), Honarbakhsh et al. (2013), Wijaya (2010), Gayatri dan Mustanda (2014), Sartini dan Purbawangsa (2014), serta Pertiwi, dkk. (2016) memperoleh hasil bahwa keputusan investasi berpengaruh positif dan signifikan terhadap nilai perusahaan. Berdasarkan teori dan hasil penelitian sebelumnya, maka hipotesis yang diajukan dalam penelitian ini yaitu:

$\mathrm{H}_{1}$ : Keputusan Investasi berpengaruh secara positif dan signifikan terhadap nilai perusahaan food and beverage.

Setiap perusahaan akan mengharapkan adanya struktur modal optimal, yaitu struktur modal yang dapat memaksimalkan nilai perusahaan (Fenandar dan Raharja, 2012). Dananjaya dan Mustanda (2016) dalam penelitiannya memperoleh hasil bahwa keputusan pendanaan berpengaruh positif tapi tidak signifikan terhadap nilai perusahaan. Sedangkan Sartini dan Purbawangsa (2014) memperoleh hasil bahwa keputusan pendanaan berpengaruh positif signifikan terhadap nilai perusahaan, mengindikasikan bahwa semakin tinggi perusahaan menggunakan modal asing, maka akan terjadi kecenderungan semakin tinggi harga saham perusahaan. Penelitian serupa oleh Himawan dan Christiawan (2016), Afzal dan 
Asri Pawestri Setyo Utami, Pengaruh Keputusan Investasi, Keputusan Pendanaan dan ...

Rohman (2012), Wijaya dan Wibawa (2010), Kumar et al. (2012), Moradi et al. (2012), Wijaya dkk. (2010), juga memperoleh hasil bahwa keputusan pendanaan berpengaruh positif signifikan terhadap nilai perusahaan. Berdasarkan hasil penelitian sebelumnya, maka dapat dirumuskan hipotesis sebagai berikut :

$\mathrm{H}_{2}$ : Keputusan pendanaan berpengaruh secara positif dan signifikan terhadap nilai perusahaan food and beverage.

Kebijakan dividen menentukan berapa banyak keuntungan yang akan diperoleh pemegang saham. Keuntungan yang akan diperoleh pemegang saham ini akan menetukan kesejahteraan para pemegang saham yang merupakan tujuan utama perusahaan. Sartini dan Purbawangsa (2014) memperoleh hasil bahwa kebijakan dividen berpengaruh positif signifikan terhadap keputusan pendanaan, mengindikasikan bahwa semakin tinggi perusahaan membagikan dividen, maka terjadi kecenderungan perusahaan menggunakan modal asing lebih besar dibandingkan penggunaan modal sendiri. Penelitian serupa oleh Uwuigbe et al., (2012). Salawu et al. (2012), Ashamu et al. (2012), serta Zulfahmi dan Pinem (2014) memperoleh hasil bahwa variabel kebijakan dividen berpengaruh positif dan signifikan terhadap nilai perusahaan. Berdasarkan penelitian terdahulu, maka dapat dirumuskan hipotesis sebagai berikut :

$\mathrm{H}_{3}$ : Kebijakan Dividen berpengaruh secara positif dan signifikan terhadap nilai perusahaan food and beverage.

\section{METODE PENELITIAN}

Pendekatan yang digunakan dalam penelitian ini adalah pendekatan kuantitatif berbentuk asosiatif yang bertujuan untuk mengetahui hubungan antara 
dua variabel atau lebih. Berdasarkan penelusuran kajian pustaka dan hasil-hasil penelitian terdahulu, maka model penelitian dapat digambarkan seperti pada Gambar 1.

\section{Gambar 1 Kerangka Konseptual Penelitian}

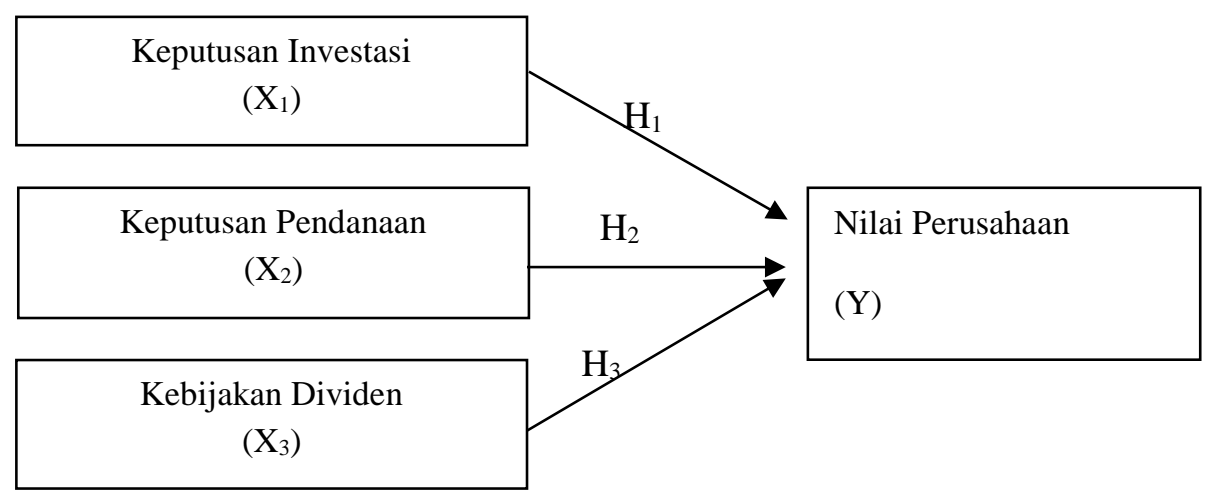

Sumber: Hasil pemikiran peneliti, 2017

Ruang lingkup wilayah penelitian ini adalah perusahaan pada sektor food and beverages yang terdaftar di Bursa Efek Indonesia (BEI) periode 2013-2016 dengan mengakses website www.idx.co.id. Obyek dalam penelitian ini adalah nilai perusahaan yang diproksikan dengan PBV pada sektor food and beverages yang terdaftar di Bursa Efek Indonesia (BEI) periode 2013-2016. Variabel independen dalam penelitian ini adalah adalah keputusan investasi $\left(\mathrm{X}_{1}\right)$, keputusan pendanaan $\left(\mathrm{X}_{2}\right)$, dan kebijakan dividen $\left(\mathrm{X}_{3}\right)$. Variabel dependen dalam penelitian ini adalah nilai perusahaan $(\mathrm{Y})$.

Nilai perusahaan dalam penelitian ini diukur dengan Price book Value $(P B V)$ pada perusahaan food and beverages yang terdaftar di Bursa Efek Indonesia (BEI) periode 2013-2016. Price to book value (PBV) adalah perhitungan atau perbandingan antara market value dengan book value perusahaan. Rumus untuk 
Asri Pawestri Setyo Utami, Pengaruh Keputusan Investasi, Keputusan Pendanaan dan ...

menghitung Price to book Value menurut Brigham dan Houston (2006:112) adalah sebagai berikut:

$P B V=\frac{\text { harga pasar per saham }}{\text { nilai buku per saham }} \times 100 \%$

Keputusan investasi dalam penelitian ini diukur dengan FAR (Fixed Asssets Ratio) pada perusahaan food and beverages yang terdaftar di Bursa Efek Indonesia (BEI) periode 2013-2016, dimana PER menunjukkan seberapa besar proporsi aktiva tetap terhadap seluruh aktiva perusahaan. Rasio yang tinggi menunjukkan penggunaan (proporsi) aktiva tetap perusahaan juga tinggi. FAR dihitung dengan membandingkan total aktiva tetap terhadap total seluruh aktiva perusahaan. Rumus untuk menghitung FAR menurut Sutrisno (2016:226) adalah sebagai berikut :

Struktur Aktiva $(F A R)=\frac{\text { fixed asset }}{\text { total asset }} \times 100 \%$

Keputusan pendanaan dalam penelitian ini diukur dengan Debt to Asset Ratio (DAR) pada perusahaan food and beverages yang terdaftar di Bursa Efek Indonesia (BEI) periode 2013-2016. Rasio ini menyatakan proporsi hutang perusahaan terhadap total aktivanya sehingga dapat menunjukkan bagaimana manajemen mengelola sumber dananya. Rumus untuk menghitung DAR menurut Harahap (2010:304) adalah sebagai berikut :

DAR $=\frac{\text { Total Hutang }}{\text { Total Aktiva }} \times 100 \%$

Kebijakan dividen dalam penelitian ini diukur dengan Dividend Payout Ratio (DPR) pada perusahaan food and beverages yang terdaftar di Bursa Efek Indonesia (BEI) periode 2013-2016, dimana rasio pembayaran dividen diukur dengan cara membagi besarnya dividen per lembar saham dengan laba bersih per 
lembar saham. Rumus untuk menghitung DPR menurut Gumanti (2013:22) adalah sebagai berikut :

$D P R=\frac{D P S}{E P S} \times 100 \%$

Data kualitatif yang digunakan dalam penelitian ini adalah daftar perusahaan yang termasuk ke dalam sektor food and beverages di Bursa Efek Indonesia (BEI) yang diteliti dari tahun 2013-2016. Data kuantitatif yang digunakan dalam penelitian ini adalah laporan keuangan perusahaan food and beverages periode 2013-2016 yang terdaftar pada Bursa Efek Indonesia. Sumber data yang digunakan dalam penelitian ini adalah data sekunder. Data dalam penelitian ini diperoleh dari data laporan keuangan tahunan perusahaan manufaktur khususnya sektor food and beverages di Bursa Efek Indonesia (BEI) periode 20132016 dengan mengakses pada situs resmi BEI yaitu www.idx.com.

Populasi yang digunakan dalam penelitian ini adalah perusahaan yang dikategorikan ke dalam sektor food and beverages yang terdaftar di Bursa Efek Indonesia (BEI) pada periode 2013-2016 dengan jumlah 15 perusahaan. Metode penentuan sampel yang digunakan dalam penelitian ini adalah purposive sampling. Data sekunder yang diperoleh kemudian dipilih berdasarkan kriteria-kriteria yang telah ditentukan. Terdapat 2 perusahaan yang tidak memenuhi kriteria penelitian, sehingga jumlah sampel penelitian ini adalah sebanyak 13 perusahaan food and beverages selama periode tahun 2013 sampai dengan tahun 2016. Pada penelitian ini, peneliti melakukan pengamatan pada annual report perusahaan food and beverage yang telah dipublikasikan melalui situs resmi Bursa Efek Indonesia (www.idx.co.id). 
Asri Pawestri Setyo Utami, Pengaruh Keputusan Investasi, Keputusan Pendanaan dan ...

Teknik analisis data yang digunakan dalam penelitian ini adalah teknik analisis regresi linier berganda, Adapun persamaan linier berganda dirumuskan secara matematis sebagai berikut :

$Y=\alpha+\beta_{1} X_{1}+\beta_{2} X_{2}+\beta_{3} X_{3}+e$

Sebelum melakukan pengujian dengan menggunakan analisis regresi linier berganda, terlebih dahulu perlu dilakukan pengujian asumsi. Uji asumsi klasik dalam penelitian ini yaitu uji normalitas, uji multikolinearitas, uji autokorelasi, dan uji heteroskedastisitas. Uji t digunakan untuk mengetahui seberapa besar pengaruh dari variabel independen $(\mathrm{X})$ secara individu (parsial) terhadap variabel dependen (Y). Koefisien determinan $\left(\mathrm{R}^{2}\right)$ digunakan untuk melihat seberapa besar pengaruh variabel - variabel independent terhadap variabel dependen.

\section{HASIL DAN PEMBAHASAN}

\section{Analisis Data}

Deskripsi variabel penelitian menyampaikan informasi mengenai karakteristik variabel-variabel penelitian yang terdiri dari jumlah pengamatan, nilai minimum, nilai maksimum, nilai rata dan standar deviasi. Tabel 1 memperlikatkan hasil analisis statistik deskriptif variabel penelitian.

Tabel 1 menunjukkan bahwa jumlah data yang digunakan dalam penelitian ini berjumlah 52 sampel. Data menjelaskan bahwa keputusan investasi memiliki nilai paling rendah (minimum) adalah sebesar 8,04 persen dimiliki oleh perusahaan PT Delta Djakarta, Tbk dengan kode DLTA pada tahun 2016 dan keputusan investasi yang paling tinggi (maksimum) adalah sebesar 100 persen yang dimiliki 
oleh perusahaan PT Tiga Pilar Sejahtera Food, Tbk dengan kode AISA pada tahun 2015 dan 2016. Keputusan pendanaan memiliki nilai paling rendah (minimum) adalah sebesar 0 persen yang dimiliki oleh perusahaan Jaya PT Prashida Aneka Niaga, Tbk dengan kode PSDN pada tahun 2013 dan keputusan pendanaan yang paling tinggi (maksimum) adalah sebesar 0,78 persen yang dimiliki oleh perusahaan PT Multi Bintang Indonesia, Tbk dengan kode MLBI pada tahun 2016.

Tabel 1. Statistik Deskriptif

\begin{tabular}{|c|c|c|c|c|c|}
\hline & $\mathrm{N}$ & Minimum & Maximum & Mean & Std. Deviation \\
\hline Keputusan Investasi & 52 & 8.04 & 100.00 & 49.5542 & 20.87258 \\
\hline Keputusan Pendanaan & 52 & .00 & .78 & .4494 & .15650 \\
\hline Kebijakan Dividen & 52 & .00 & 145.92 & 28.8855 & 26.12933 \\
\hline Nilai Perusahaan & 52 & .00 & 48.67 & 5.9056 & 9.70857 \\
\hline Valid N (listwise) & 52 & & & & \\
\hline
\end{tabular}
Sumber: Data diolah, 2017

Kebijakan dividen mempunyai nilai paling kecil (minimum) sebesar 0 persen yang dimiliki oleh perusahaan PT Delta Djakarta, Tbk dengan kode DLTA pada tahun 2016 dan kebijakan dividen paling besar (maksimum) sebesar 145,92 persen yang dimiliki oleh perusahaan PT Multi Bintang Indonesia, Tbk dengan kode MLBI pada tahun 2015. Nilai perusahaan memiliki nilai paling rendah (minimum) adalah sebesar 0 persen yang dimiliki oleh perusahaan PT Cahaya Kalbar, Tbk dengan kode CEKA pada tahun 2016 dan nilai perusahaan yang paling tinggi (maksimum) adalah sebesar 48,67 persen yang dimiliki oleh perusahaan PT Multi Bintang Indonesia, Tbk dengan kode MLBI pada tahun 2014.

Uji asumsi klasik dilakukan dengan tujuan untuk memastikan hasil yang diperoleh memenuhi asumsi dasar di dalam analisis regresi. Hasil uji asumsi klasik 
Asri Pawestri Setyo Utami, Pengaruh Keputusan Investasi, Keputusan Pendanaan dan ...

yang dilakukan dalam penelitian ini adalah uji normalitas, uji multikoliniearitas, uji autokorelasi dan uji heteroskedastisitas.

Uji normalitas bertujuan untuk menguji apakah dalam model regresi memiliki distribusi normal atau tidak. Hasil uji normalitas untuk seluruh sampel dapat dilihat pada Tabel 2 di bawah ini.

Tabel 2.

Hasil Uji Normalitas

\begin{tabular}{ll}
\hline & Unstandardized Residual \\
\hline $\mathrm{N}$ & 52 \\
Kolmogorov-Smirnov $Z$ & 0,603 \\
Asymp.Sig.(2-tailed) & 0,861 \\
\hline
\end{tabular}
Sumber: Data diolah, 2017

Berdasarkan pada Tabel 2, hasil pengujian normalitas pada persamaan regresi linear berganda menunjukkan bahwa nilai Asymp. Sig (2-tailed) 0,861 lebih besar dari level of significant, yaitu 5 persen $(0,05)$ sehingga data yang diuji menyebar normal atau berdistribusi normal.

Uji multikolinearitas bertujuan untuk menguji apakah model regresi di temukan adanya korelasi antar variabel bebas. Untuk mendeteksi ada atau tidaknya multikolinearitas pada model regresi dapat dilihat pada nilai tolerance dan nilai variance inflation factor (VIF). Jika nilai tolerance lebih dari 10 persen atau VIF kurang dari 10, maka dikatakan tidak ada multikolinearitas. Hasil uji multikolinearitas dapat dilihat pada Tabel 3 berikut.

Tabel 3.

\section{Hasil Uji Multikolinearitas}

\begin{tabular}{lll}
\hline Variabel & Tolerance & VIF \\
\hline Keputusan Investasi $\left(\mathrm{X}_{1}\right)$ & 0,918 & 1,089 \\
Keputusan Pendanaan $\left(\mathrm{X}_{2}\right)$ & 0,930 & 1,075 \\
Kebijakan Dividen $\left(\mathrm{X}_{3}\right)$ & 0,950 & 1,053 \\
\hline
\end{tabular}


Berdasarkan Tabel 3 dapat disimpulkan bahwa nilai tolerance persamaan regresi linear berganda masing-masing variabel bernilai diatas $10 \%(0,10)$ dan nilai VIF dibawah 10. Hal ini menunjukkan bahwa model regresi yang ada tidak terjadi gejala multikolinearitas.

Uji autokorelasi dilakukan untuk melacak adanya korelasi data dari tahun $\mathrm{t}$ dengan tahun t-1 (sebelumnya). Pengujian autokorelasi dilakukan melalui DurbinWatson test, dimana model regresi dikatakan terbebas dari autokorelasi apabila sesuai dengan kriteria du $<\mathrm{DW}<4$-du. Hasil uji autokorelasi dapat dilihat pada Tabel 4 berikut.

Tabel 4.

Hasil Uji Autokorelasi

\begin{tabular}{|c|c|c|c|c|}
\hline DI & Du & DW & 4-Du & Simpulan \\
\hline 1,434 & 1,677 & 2,268 & 2,323 & Bebas autokorelasi \\
\hline
\end{tabular}

Sumber: Data diolah, 2017

Tabel 4 menunjukkan nilai Durbin-Watson sebesar 2,268. Untuk tingkat signifikansi $5 \%$, nilai $\mathrm{dl}=1,434$ dan $\mathrm{du}=1,677$. Dengan demikian hasil uji autokorelasi dengan kriteria du $<\mathrm{DW}<4$-du adalah 1,677 $<2,268<2,23$, maka dapat disimpulkan bahwa model regresi yang dibuat tidak mengandung gejala autokorelasi.

Uji heteroskedastisitas dilakukan untuk menguji model regresi apakah terjadi ketidaksamaan varian dari residual satu pengamatan ke pengamatan lain. Uji heteroskedastisitas pada penelitian ini menggunakan uji Glejser. Uji Glejser dilakukan dengan cara meregresi nilai absolute residual dari model yang diestimasi terhadap variabel bebas. Jika nilai signifikannya lebih dari 0,05 maka tidak terjadi gejala heterosedastositas. 
Tabel 5.

Hasil Uji Heteroskedastisitas

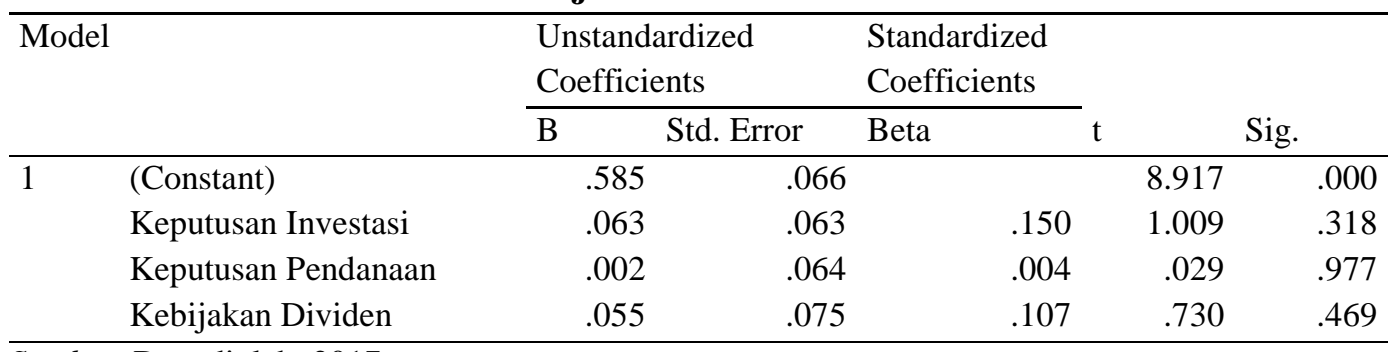

Sumber: Data diolah, 2017

Tabel 5 menunjukkan bahwa nilai sigifikansi dari variabel keputusan investasi, keputusan pendanaan dan kebijakan dividen masing-masing sebesar 0,318; 0,977 dan 0,469. Nilai tersebut lebih besar dari 0,05 yang berarti tidak terdapat pengaruh antara variabel bebas terhadap absolute residual. Dengan demikian, model yang dibuat tidak mengandung gejala heteroskedastisitas.

Analisis regresi linier berganda ini digunakan untuk menganalisis pengaruh keputusan investasi $\left(\mathrm{X}_{1}\right)$, keputusan pendanaan $\left(\mathrm{X}_{2}\right)$ dan kebijakan dividen $\left(\mathrm{X}_{3}\right)$ terhadap nilai perusahaan (Y). Hasil analisis regresi linier berganda dalam penelitian ini ditunjukkan pada Tabel 6 berikut:

Tabel 6.

Hasil Uji Regresi Linear Berganda

\begin{tabular}{|c|c|c|c|}
\hline Variabel & Nilai Koefisien Regresi & t hitung & Nilai Signifikansi \\
\hline Constant & $-0,153$ & $-1,415$ & 0,164 \\
\hline Keputusan Investasi & 0,218 & 2,106 & 0,040 \\
\hline Keputusan Pendanaan & 0,382 & 3,605 & 0,001 \\
\hline Kebijakan Dividen & 0,293 & 2,363 & 0,022 \\
\hline R Square & & & 0,373 \\
\hline Adjusted R Square & & & 0,334 \\
\hline F Hitung & & & 9,535 \\
\hline Signifikansi & & & 0,000 \\
\hline
\end{tabular}

Sumber: Data diolah, 2017

Berdasarkan Tabel 6 dapat disusun persamaan regresi sebagai berikut :

$Y=\alpha+\beta_{1} X_{1}+\beta_{2} X_{2}+\beta_{3} X_{3}+\varepsilon$

$Y=-1,153+0,218 X_{1}+0,382 X_{2}+0,293 X_{3}+\varepsilon$ 
Nilai konstanta pada persamaan regresi sebesar -1.153, hal ini berarti jika nilai keputusan investasi, keputusan pendanaan dan kebijakan dividen sama dengan nol, maka nilai perusahaan tidak meningkat atau sama dengan $-1,153$ persen. Koefisien regresi $\left(b_{1}\right)$ pada keputusan investasi $\left(\mathrm{X}_{1}\right)$ bernilai 0,218 mempunyai hubungan positif pada nilai perusahaan. Artinya, bila nilai keputusan investasi $\left(\mathrm{X}_{1}\right)$ bertambah satu persen, maka nilai perusahaan (Y) akan mengalami peningkatan sebesar 21,8 persen dengan asumsi variabel bebas lainnya konstan. Koefisien regresi $\left(b_{2}\right)$ pada keputusan pendanaan $\left(\mathrm{X}_{2}\right)$ bernilai 0,382 mempunyai hubungan positif pada nilai perusahaan. Artinya, bila nilai keputusan pendanaan $\left(\mathrm{X}_{2}\right)$ bertambah satu persen, maka nilai perusahaan (Y) akan mengalami peningkatan sebesar 38,2 persen dengan asumsi variabel bebas lainnya konstan. Koefisien regresi $\left(b_{3}\right)$ pada kebijakan dividen $\left(X_{3}\right)$ bernilai 0,293 mempunyai hubungan positif pada nilai perusahaan. Artinya, bila nilai kebijakan dividen $\left(\mathrm{X}_{3}\right)$ bertambah satu persen, maka nilai perusahaan (Y) akan mengalami peningkatan sebesar 29,3 persen dengan asumsi variabel bebas lainnya konstan.

Nilai adjusted $R^{2}$ sebesar 0,334 mempunyai arti bahwa sebesar 33,4\% variasi nilai perusahaan dipengaruhi oleh variasi keputusan investasi, keputusan pendanaan dan kebijakan dividen, sedangkan sisanya sebesar $66,6 \%$ djelaskan oleh faktor lain yang tidak dimasukkan ke dalam model. Hasil uji $\mathrm{F}$ ( F test) menunjukkan bahwa nilai $\mathrm{F}$ hitung sebesar 9,535 dengan nilai signifikansi $\mathrm{P}$ value 0,000 yang lebih kecil dari $\alpha=0,05$, ini berarti model yang digunakan pada penelitian ini adalah layak. Hasil ini memberikan makna bahwa ke tiga variabel independen yaitu keputusan investasi, keputusan pendanaan dan kebijakan dividen mampu memprediksi atau 
Asri Pawestri Setyo Utami, Pengaruh Keputusan Investasi, Keputusan Pendanaan dan ...

menjelaskan fenomena nilai perusahaan manufaktur yang terdaftar di BEI periode 2013 - 2016. Hal ini berarti model dapat digunakan untuk analisa lebih lanjut atau dengan kata lain model dapat digunakan untuk memproyeksikan karena hasil goodness of fitnya baik dengan nilai F hitung sebesar 9,535 dengan nilai signifikansi $\mathrm{P}$ value 0,000 .

\section{Pengaruh Keputusan Investasi Terhadap Nilai Perusahaan}

Pada Tabel 6 dapat dilihat bahwa hasil analisis pengaruh keputusan investasi terhadap nilai perusahaan diperoleh nilai Sig. t 0,040 dengan nilai koefisien beta 0,218. Nilai Sig. t 0,040 < 0,05 mengindikasikan bahwa $\mathrm{H}_{0}$ ditolak dan $\mathrm{H}_{1}$ diterima. Hasil ini mempunyai arti bahwa keputusan investasi berpengaruh positif dan signifikan terhadap nilai perusahaan food and beverage. Semakin tinggi tingkat keputusan investasi yang ditetapkan perusahaan maka akan menghasilkan kesempatan yang tinggi pula untuk mendapatkan keuntungan yang besar.

Keputusan investasi merupakan ketetapan yang dibuat oleh pihak perusahaan dalam membelanjakan dana yang dimilikinya dalam bentuk aset tertentu dengan harapan mendapatkan keuntungan di masa yang akan datang. Semakin tinggi tingkat keputusan investasi yang ditetapkan perusahaan maka akan menghasilkan kesempatan yang tinggi pula untuk mendapatkan keuntungan yang besar. Dengan perusahaan yang memiliki keputusan investasi yang tinggi maka mampu untuk memengaruhi pemahaman investor untuk tertarik dalam melakukan investasi kepada perusahaan tersebut sehingga mampu meningkatkan permintaan terhadap saham pada perusahaan (Pertiwi dkk., 2016). Hasil penelitian ini didukung oleh penelitian Safitri dan Wahyuati (2015), Yuliani (2013), Fenandar dan Raharja 
(2012), Afzal dan Rohman, 2012), Dananjaya dan Mustanda (2016), Rizqia et al. (2013), Honarbakhsh et al. (2013), Wijaya (2010), Gayatri dan Mustanda (2014), Sartini dan Purbawangsa (2014), serta Pertiwi dkk. (2016) yang menemukan hasil bahwa keputusan investasi berpengaruh positif dan signifikan terhadap nilai perusahaan.

\section{Pengaruh Keputusan Pendanaan Terhadap Nilai Perusahaan}

Pada Tabel 6 dapat dilihat bahwa hasil analisis pengaruh keputusan pendanaan terhadap nilai perusahaan diperoleh nilai Sig. t sebesar 0,001 dengan nilai koefisien beta 0,382 . Nilai Sig. t 0,001 $<0,05$ mengindikasikan bahwa $\mathrm{H}_{0}$ ditolak dan $\mathrm{H}_{1}$ diterima. Hasil ini mempunyai arti bahwa keputusan pendanaan berpengaruh positif dan signifikan terhadap nilai perusahaan food and beverage. Keputusan pendanaan dapat diartikan sebagai keputusan yang menyangkut struktur keuangan perusahaan.

Keputusan pendanaan dapat diartikan sebagai keputusan yang menyangkut struktur keuangan perusahaan. Struktur keuangan perusahaan merupakan komposisi dari keputusan pendanaan yang meliputi hutang jangka pendek, hutang jangka panjang dan modal sendiri. Setiap perusahaan akan mengharapkan adanya struktur modal optimal, yaitu struktur modal yang dapat memaksimalkan nilai perusahaan (Fenandar dan Raharja, 2012).

Hasil penelitian ini didukung dengan penelitian yang dilakukan oleh Sartini dan Purbawangsa (2014) yang memperoleh hasil bahwa keputusan pendanaan berpengaruh positif signifikan terhadap nilai perusahaan, mengindikasikan bahwa semakin tinggi perusahaan menggunakan modal asing, maka akan terjadi 
Asri Pawestri Setyo Utami, Pengaruh Keputusan Investasi, Keputusan Pendanaan dan ...

kecenderungan semakin tinggi harga saham perusahaan. Menurut Sartono (2010:228), pendekatan laba bersih mengasumsikan bahwa investor mengkapitalisasi atau menilai laba perusahaan dengan tingkat kapitalisasi yang konstan dan perusahaan dapat meningkatkan jumlah utangnya dengan tingkat biaya utang yang konstan pula. Karena biaya modal sendiri dan tingkat bunga utang konstan maka semakin besar jumlah utang yang digunakan perusahaan, biaya modal rata-rata tertimbang akan semakin kecil, karena biaya utang lebih rendah daripada biaya modal sendiri. Oleh karena itu jika biaya modal rata-rata tertimbang semakin kecil sebagai akibat penggunaan utang yang semakin besar, nilai perusahaan akan meningkat.

Hasil penelitian ini sama hasilnya dengan penelitian yang dilakukan Wijaya dan Wibawa (2010) yang menyebutkan adanya hubungan positif antara keputusan pendanaan dengan nilai perusahaan. Dalam penelitiannya menyebutkan bahwa apabila pendanaan didanai melalui hutang, maka peningkatan nilai perusahaan terjadi akibat efek tax deductible, yaitu perusahaan yang memiliki hutang akan membayar bunga pinjaman yang dapat mengurangi penghasilan kena pajak, yang dapat memberikan manfaat bagi pemegang saham. Penelitian serupa oleh Himawan dan Christiawan (2016), Afzal dan Rohman (2012), Kumar et al. (2012), Moradi et al. (2012), Wijaya dkk. (2010), juga memperoleh hasil bahwa keputusan pendanaan berpengaruh positif signifikan terhadap nilai perusahaan.

\section{Pengaruh Kebijakan Dividen Terhadap Nilai Perusahaan}

Pada Tabel 6 dapat dilihat bahwa hasil analisis pengaruh kebijakan dividen terhadap nilai perusahaan diperoleh nilai Sig. t 0,022 dengan nilai koefisien beta 
0,293. Nilai Sig. t 0,022 < 0,05 mengindikasikan bahwa $\mathrm{H}_{0}$ ditolak dan $\mathrm{H}_{1}$ diterima. Hasil ini mempunyai arti bahwa kebijakan dividen berpengaruh positif dan signifikan terhadap nilai perusahaan food and beverage. Kebijakan dividen menentukan berapa banyak keuntungan yang akan diperoleh pemegang saham.

Kebijakan dividen menentukan berapa banyak keuntungan yang akan diperoleh pemegang saham. Keuntungan yang akan diperoleh pemegang saham ini akan menetukan kesejahteraan para pemegang saham yang merupakan tujuan utama perusahaan. Hasil penelitian ini sesuai dengan bird-in-the-hand theory yang menyatakan bahwa semakin tinggi dividen yang dibagikan oleh perusahaan maka akan semakin tinggi pula nilai suatu perusahaan. Nilai perusahaan akan dimaksimalkan dengan rasio pembayaran dividen yang tinggi. Dengan dividend payout ratio yang tinggi maka biaya modal sendiri akan turun, karena investor kurang pasti terhadap capital gain akibat laba ditahan yang di reinvestasi dibanding penerimaan dividen, karena peningkatan harga saham akibat pertumbuhan masih belum pasti (Brigham dan Houston, 2006:112). Hasil penelitian ini didukung oleh Sartini dan Purbawangsa (2014), Uwuigbe et al. (2012), Salawu et al. (2012), Ashamu et al. (2012), serta Zulfahmi dan Pinem (2014) yang memperoleh hasil bahwa variabel kebijakan dividen berpengaruh positif dan signifikan terhadap nilai perusahaan.

\section{SIMPULAN DAN SARAN}

Berdasarkan pembahasan yang telah diuraikan, maka diperoleh simpulan sebagai berikut: (1) keputusan investasi berpengaruh secara positif dan signifikan terhadap nilai perusahaan food and beverage yang terdaftar di BEI periode 2013- 
Asri Pawestri Setyo Utami, Pengaruh Keputusan Investasi, Keputusan Pendanaan dan ...

2016, mengindikasikan bahwa semakin tinggi tingkat keputusan investasi yang ditetapkan perusahaan maka semakin meningkat pula nilai dari perusahaan tersebut. (2) Keputusan pendanaan berpengaruh secara positif dan signifikan terhadap nilai perusahaan food and beverage yang tedaftar di BEI periode 2013-2016, mengindikasikan bahwa semakin tinggi perusahaan menggunakan modal asing, maka akan terjadi kecenderungan semakin tinggi harga saham perusahaan tersebut. (3) Kebijakan dividen berpengaruh secara positif dan signifikan terhadap nilai perusahaan food and beverage yang tedaftar di BEI periode 2013-2016, mengindikasikan bahwa semakin tinggi perusahaan membagikan dividen, maka terjadi kecenderungan perusahaan menggunakan modal asing lebih besar dibandingkan penggunaan modal sendiri.

Berdasarkan hasil penelitian dan kesimpulan, maka saran-saran yang dapat diberikan adalah sebagai berikut: (1) perusahaan food and beverages yang terdaftar di BEI disarankan agar lebih memperhatikan lagi faktor internal perusahaan yang dimiliki. Variabel tersebut dapat dijadikan acuan untuk menentukkan strategi mereka dalam meningkatkan nilai perusahaan. Nilai perusahaan yang baik menunjukan tingkat kesehatan keuangan perusahaan yang baik akan membuat nilai perusahaan akan meningkat dan akan di minati oleh investor. (2) Peneliti selanjutnya disarankan untuk menambah pengaruh faktor eksternal perusahaan, seperti variabel tingkat suku bunga, tingkat inflasi, kurs mata uang, dan situasi sosial politik dalam penelitian ini sehingga dapat memperluas penelitian ini. (3) Peneliti selanjutnya juga diharapkan untuk menambah periode penelitian dan 
memperluas sampel penelitian yang digunakan, sehingga tidak hanya berfokus pada perusahaan food and beverage.

\section{REFERENSI}

Afzal, A. dan Abdul R. 2012. Pengaruh Keputusan Investasi, Keputusan Pendanaan, Dan Kebijakan Deviden Terhadap Nilai Perusahaan. Diponegoro Journal of Accounting, 1 (2), 1-9.

Aldivitto, D. 2012. The Impact of Working Capital Components TurnoverPeriod Towards Market Value Ratio. Jurnal International Accounting, Faculty of Economics and Business, 18 (3), 60-68

Azhar, N. E. dan Noriza. 2010. Working capital management: The effect of Market Valuation and Profitability in Malaysia. International Journal of Business and Management, 5 (11), 1-10

Brigham, E. F and Joel F. H. 2006. Manajemen Keuangan. Edisi Kedelapan. Buku 1. Jakarta : Erlangga.

Bursa Efek Indonesia. 2017. www.idx.co.id.

Dananjaya, P.M. dan I.K Mustanda. 2016. Pengaruh Keputusan Investasi, Keputusan Pendanaan, Dan Kebijakan Dividen Terhadap Nilai Perusahaan Pada Perusahaan Manufaktur. E-Jurnal Manajemen Unud, 5 (10), 66106639.

Fama, E. F. 1978. The Effect of a Firm's Investment and Financing Decision on the Welfare of its Security Holders. American Economic Review 68(1), 27228.

Fenandar, G.I. dan S. Raharja. 2012. Pengaruh Keputusan Investasi, Keputusan Pendanaan, Dan Kebijakan Dividen Terhadap Nilai Perusahaan. Diponegoro Journal of Accounting, 1 (2), 1-10.

Himawan, M.R. dan Y.J Christiawan. 2016. Pengaruh Keputusan Pendanaan Dan Kebijakan Dividen Terhadap Nilai Perusahaan Pada Sektor Manufaktur Di Indonesia. Business Accounting Review, 4(1), 193-204.

Husnan, S. 2004. Dasar-dasar Teori Portofolio dan Analisis Sekuritas. Yogyakarta: UPP AMP YKPN. 
Asri Pawestri Setyo Utami, Pengaruh Keputusan Investasi, Keputusan Pendanaan dan ...

Husnan, S. 2010. Manajemen Keuangan Teori dan Penerapan (Keputusan Jangka Panjang., Edisi 4. BPFE-Yogyakarta, Yogyakarta.

Honarbakhsh, S., Birjandi, H., and Birjandi M. 2013. The Effects of Dividend Policy on Market Value on Companies Listed In Tehran Stock Exchange. International Review of Management and Business Research, 1(1), 65-75.

Hossain, M. Ahmed, K. Godfrey, J. M. 2005. Investment Opportunity Set and Voluntary Disclosure of Prospective Information: A Simultaneous Equation Approach. Journal of Business Finance \& Accounting. 32 (5), 871-907.

Kumar, S., Anjum, B., and Nayyar, S. 2012. Financing Decisions: Studi of Pharmaceutical Companies of India. International Journal of Marketing, Financial Services \& Management Research, 1(1), 14-28.

Pertiwi, P.J., Parengkuan T., dan Johan R. T. 2016. Pengaruh Kebijakan Hutang, Keputusan Investasi dan Profitabilitas Terhadap Nilai Perusahaan Food And Beverages Yang Terdaftar Di Bursa Efek Indonesia. Jurnal EMBA, 4(1), 1369-1380.

Okpara, Godwin Chigozie. 2010. AsyModiglani dan Milleretric Information And Dividen Policy in Emerging Markets : Empirical Evidence From Nigeria. International Journal Of Economics And Finance, 2(4), 212-220.

Rudangga, I G.N.G. 2016. Pengaruh Ukuran Perusahaan, Leverage, dan Profitabilitas Terhadap Nilai Perusahaan Pada Perusahaan (Pada Perusahaan Foods and Beverages Yang Terdaftar Di Bursa Efek Indonesia). Skripsi. Fakultas Ekonomi Universitas Udayana.

Safitri, N. dan A. Wahyuati. 2015. Pengaruh Struktur Modal Dan Keputusan Investasi Terhadap Profitabilitas dan Nilai Perusahaan. Jurnal Ilmu dan Riset Manajemen, 4(2), 1-17.

Saputri, A.Y. Sulastri, dan S. W. Bakar. 2016. Pengaruh Keputusan Investasi Terhadap Nilai Perusahaan Pada Perusahaan Sektor Manufaktur Sub Sektor Makanan dan Minuman Yang Terdaftar Di Bursa Efek Indonesia. Jurnal Ilmiah Manajemen Bisnis dan Terapan Tahun XIII, 13(2), 113-128.

Sartini, L.P.N. dan I.B.A. Purbawangsa. 2014 Pengaruh Keputusan Investasi, Kebijakan Dividen, Serta Keputusan Pendanaan Terhadap Nilai Perusahaan Manufaktur Di Bursa Efek Indonesia . E-Jurnal Manajemen Unud, 3 (8), 2393-2412. 
Uwigbe, U. 2012. Dividend Policy and Firm Performances : A Study of Listed Firm in Nigeria. Accounting and Management Information Systems, 11(3), 442454.

Vranakis, S. K and P. D. Chatzoglou. 2012. A Conceptual Model for Machinery and Equipment Investment Decisions. International Journal of Business and Management, 7(1), 36-5.

Wijaya, L.R.P, dan A. Wibawa, 2010, Pengaruh Keputusan Investasi, Keputusan Pendanaan, Dan Kebijakan Dividen Terhadap Nilai Perusahaan, Jurnal Nasional Akuntansi XIII Purwokerto, 13(1), 1-10.

Yuliani. 2013. Implikasi Keputusan Investasi terhadap Nilai Perusahaan Sektor Real Estate and Property di Bursa Efek Indonesia: Faktor Risiko dan Rasio Likuiditas sebagai Variabel Intervening. Jurnal Hasil Riset Ilmu Sosial, 4(2), 105-113

Zulfahmi, A.M. dan D. Pinem. 2014. Pengaruh Keputusan Investasi, Keputusan Pendanaan Dan Kebijakan Dividen Terhadap Nilai Perusahaan Pada Perusahaan Manufaktur Yang Terdaftar Di Bursa Efek Indonesia. E-Jurnal UPN Veteran Jakarta, 12(5), 510-521. 